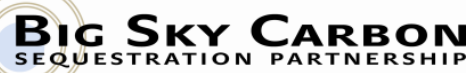

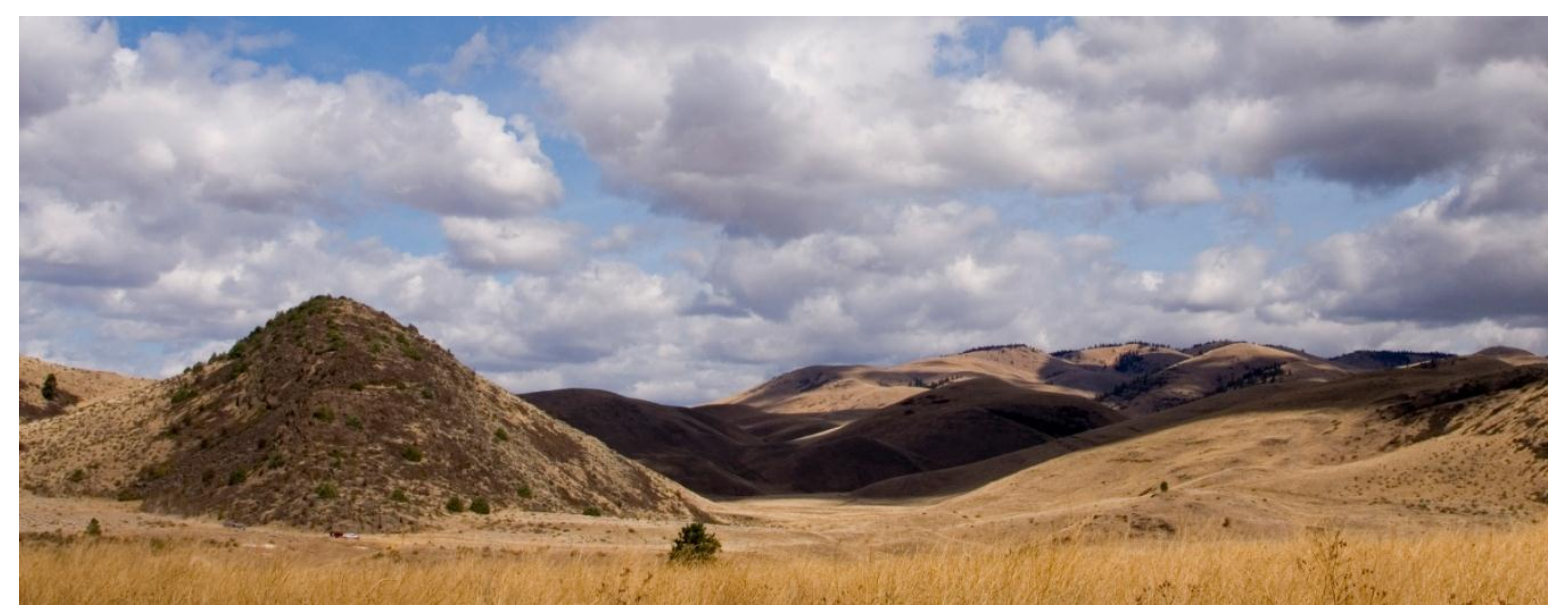

\section{RANGELAND SEQUESTRATION POTENTIAL ASSESSMENT}

Final Report

September 2011

U.S. Department of Energy (DOE)

National Energy Technology Laboratory (NETL)

DOE Award Number: DE-FC26-05NT42587

\section{Submitted by: Dr. Lee Spangler}

BSCSP Principal Investigator and Director

Montana State University

P.O. Box 173905

Bozeman, MT 59717

spangler@montana.edu

http://www.bigskyco2.org

Phone: (406) 994-4399

Fax: (406) 994-3745

BSCSP Rangeland Team

George F. Vance

Gerald E. Schuman

Justin D. Derner 


\section{Disclaimer}

This report was prepared as an account of work sponsored by an agency of the United States Government. Neither the United States Government nor any agency thereof, nor any of their employees, makes any warranty, express or implied, or assumes any legal liability or responsibility for the accuracy, completeness, or usefulness of any information, apparatus, product, or process disclosed, or represents that its use would not infringe privately owned rights. Reference herein to any specific commercial product, process, or service by trade name, trademark, manufacturer, or otherwise does not necessarily constitute or imply its endorsement, recommendation, or favoring by the United States Government or any agency thereof. The views and opinions of authors expressed herein do not necessarily state or reflect those of the United States Government or any agency thereof. 


\section{Table of Contents}

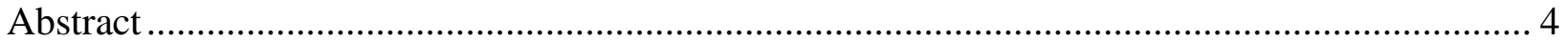

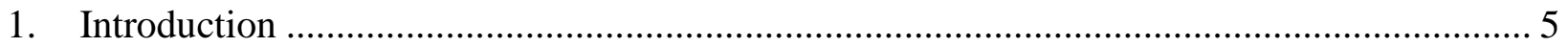

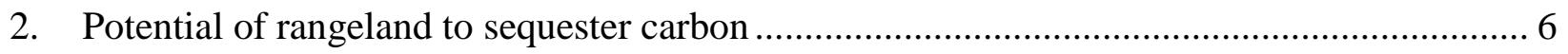

3. Impact of grazing on rangeland soil carbon pool ........................................................... 9

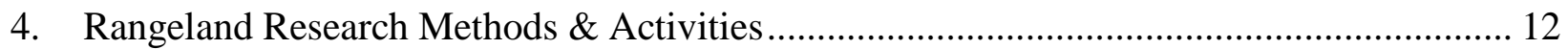

5. Example of a Management Practice for Carbon Sequestration ............. Error! Bookmark not defined.

6. Conclusion Error! Bookmark not defined.

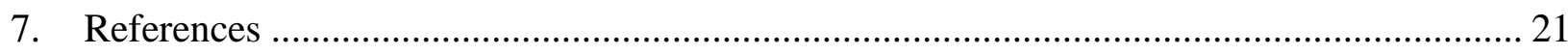

\section{Figures}

Figure 1: Departure from the long-term (1982-2003) mean annual precipitation $(424 \mathrm{~mm})$ at the

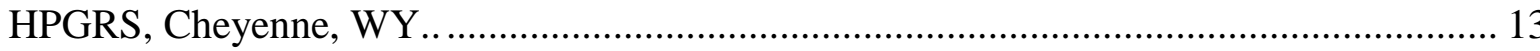

Figure 2: Canonical multivariate analysis for microbial groups.................................................. 14

Figure 3: Change (grazed vs. non-grazed, \%) in soil organic carbon with respect to length of grazing treatment in North American Great Plains......................................................... 16

Figure 4: Change (grazed vs. non-grazed, \%) in soil organic carbon change with mean annual precipitation (MAP) with grazing in North American Great Plains ...................................... 17

Figure 5: Land Resource Regions and their relative $\mathrm{C}$ sequestration rates according to the Chicago Climate Exchange. 18

\section{Tables}

Table 1: Measured \& Modeled Rangeland Carbon Sequestration (C Seq.) rates............................. 7

Table 2: Soil organic carbon mass in the non-grazed (EX), continuous, lightly grazed (CL), and continuous, heavily grazed $(\mathrm{CH})$ pastures at the High Plains Grasslands Research Station. 12

Table 3: Practices that result in a net sequestering of carbon in plants and soils 20 


\begin{abstract}
Rangelands occupy approximately half of the world's land area and store greater than $10 \%$ of the terrestrial biomass carbon and up to $30 \%$ of the global soil organic carbon. Although soil carbon sequestration rates are generally low on rangelands in comparison to croplands, increases in terrestrial carbon in rangelands resulting from management can account for significant carbon sequestration given the magnitude of this land resource. Despite the significance rangelands can play in carbon sequestration, our understanding remains limited. Researchers conducted a literature review to identify sustainably management practices that conserve existing rangeland carbon pools, as well as increase or restore carbon sequestration potentials for this type of ecosystem. The research team also reviewed the impact of grazing management on rangeland carbon dynamics, which are not well understood due to heterogeneity in grassland types. The literature review on the impact of grazing showed a wide variation of results, ranging from positive to negative to no response. On further review, the intensity of grazing appears to be a major factor in controlling rangeland soil organic carbon dynamics. In 2003, researchers conducted field sampling to assess the effect of several drought years during the period 19932002. Results suggested that drought can significantly impact rangeland soil organic carbon (SOC) levels, and therefore, carbon sequestration. Resampling was conducted in 2006; results again suggested that climatic conditions may have overridden management effects on SOC due to the ecological lag of the severe drought of 2002. Analysis of grazing practices during this research effort suggested that there are beneficial effects of light grazing compared to heavy grazing and non-grazing with respect to increased SOC and nitrogen contents. In general, carbon storage in rangelands also increases with increased precipitation, although researchers identified threshold levels of precipitation where sequestration begins to decrease.
\end{abstract}




\section{Introduction}

Rangelands occupy approximately half of the world's land area and store greater than $10 \%$ of the terrestrial biomass carbon (C) and up to $30 \%$ of the global soil organic carbon (Schlesinger 1997; Scurlock and Hall 1998). On a global scale, rangelands are estimated to sequester carbon in soil

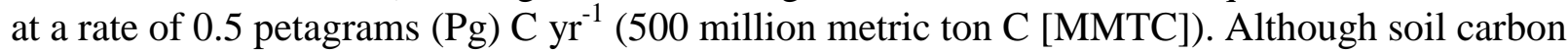
sequestration rates are generally low on rangelands in comparison to croplands, increases in terrestrial carbon in rangelands resulting from management can account for significant carbon sequestration given the magnitude of this land resource. This would signify that modest changes in rangeland carbon storage have the potential to modify the global carbon cycle and influence climate (Schimel et al. 1990; Ojima et al. 1993; Conant et al. 2001). Despite the significance rangelands can play in carbon sequestration, our understanding remains limited (Schuman et al. 2008). 


\section{Potential of rangeland to sequester carbon}

Rangelands are defined as uncultivated land areas that support grazing and browsing of animals. A wide range of ecosystems, such as native, perennial grassland, annual grassland, and tundra, are included under rangelands (Lal 2001). Rangelands cover about half of the world's terrestrial area (47\%) and contain more than a third of the above- and belowground carbon reserves (AllenDiaz 1996). In the United States, 161 million hectares (Mha) of the area is classified as rangeland, which is primarily in the central prairie region with a gradient from short grass to tall grass prairie along a moisture gradient. Due to the vast area, rangelands play an important role in soil carbon sequestration and hence can mitigate climate change due to increasing atmospheric carbon dioxide $\left(\mathrm{CO}_{2}\right)$ concentrations (Follett 2001).

In rangeland ecosystems, rates of carbon sequestration often peak during early soil formation and diminish with time, approaching a new equilibrium or steady state level (Schlesinger 1995; Chadwick et al. 1994; Schuman et al. 2008). Schuman et al. (2001) estimated that rangelands

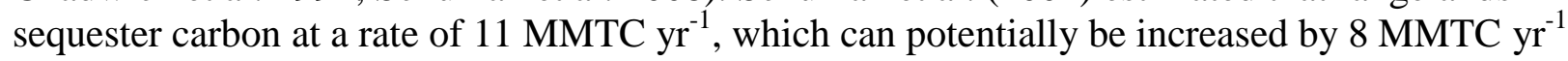
in reestablished grasslands. Schuman et al. (2001) reported that about one-third of the U.S. rangelands (54 Mha) have no serious ecological and/or management threats; therefore, the reserve rangeland soil carbon pool can be considered relatively stable. However, changes in the carbon pool can be possible due to alterations in species diversity. The remaining two-thirds of the rangelands are recognized as facing some constraints that deteriorate the soil quality and hence carbon storage. The effect of improved management or restoration of these rangelands will be slow and gradual.

In addition to conserving existing rangeland carbon pools, it is also important to develop sustainable management practices to increase or restore carbon sequestration potentials specific for this ecosystem. Recent studies evaluating the impact of grazing on carbon storage (Manley et al. 1995; Schuman et al. 1999) revealed that in Wyoming rangeland, proper grazing management practices can increase the soil carbon content at a rate of $0.3 \mathrm{MT}$ carbon $\mathrm{ha}^{-1} \mathrm{yr}^{-1}$ compared to

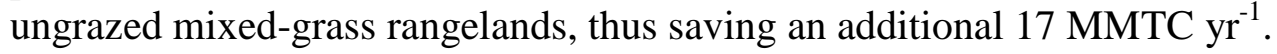

The main considerations in rangeland soil organic carbon (SOC) sequestration are:

- the aboveground carbon pool is less than $1 \%$ of the total ecosystem carbon storage and turns over every 1 to 2 years, and short-term changes of aboveground biomass alone are not likely to affect the carbon storage;

- most SOC is recalcitrant and well protected from natural disturbances and generally resists change;

- a majority of SOC input is due to the decomposition of belowground biomass; and

- a large perturbation in the SOC pool occurs during soil erosion and with site specific disturbances (Follett 2001).

The total area prone to high soil erosion may account for 123 Mha (considering rangeland and pasture together). In addition, restoration management practices that improve biomass production may sequester SOC at the rate of 100 to $200 \mathrm{~kg} \mathrm{ha}^{-1} \mathrm{yr}^{-1}$ (Lal 2001). Annual carbon emission due

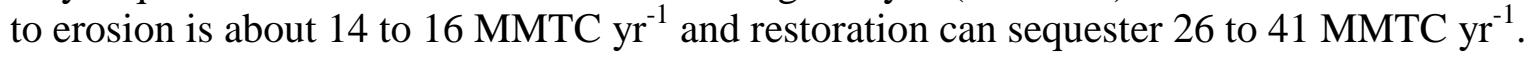
Restoration treatments may also reduce the volume of eroded sediments and hence carbon loss (Lal 2001). Several practices that have been shown to impact carbon sequestration rates on 
rangelands are shown in Table 1 and suggest that carbon sequestration rate extremes range from -2.2 to $9.3 \mathrm{Mg} \mathrm{Cha}^{-1} \mathrm{yr}^{-1}$ with rates generally less than $1 \mathrm{MgC} \mathrm{ha}^{-1} \mathrm{yr}^{-1}$ for most practices.

\begin{tabular}{|c|c|c|c|}
\hline Grassland type - Location & Management Practice & $\begin{array}{c}\text { C Seq. rate } \\
\left(M g C h a^{-1} y^{-1}\right)\end{array}$ & Citation \\
\hline \multirow{7}{*}{ U.S. Grasslands } & Potential mitigation gains & & \multirow{7}{*}{$\begin{array}{l}\text { Schuman et al. } \\
\quad(2001)\end{array}$} \\
\hline & Poorly managed grasslands (113 Mha) & 0.1 & \\
\hline & Conservation Reserve Program grasslands (13 Mha) & 0.6 & \\
\hline & Potential avoided loss & & \\
\hline & Well managed grasslands (57 Mha) & 0.3 & \\
\hline & Poorly managed grasslands (113 Mha) & 0.2 & \\
\hline & Conservation Reserve Program grasslands (13 Mha) & 0.3 & \\
\hline \multirow[t]{2}{*}{$\begin{array}{l}\text { Short-grass prairie } \\
\quad \text { Colorado }\end{array}$} & \multirow[t]{4}{*}{ Grazing } & 0.12 & $\begin{array}{c}\text { Derner et al. } \\
(1997)\end{array}$ \\
\hline & & 0.07 & $\begin{array}{c}\text { Reeder \& } \\
\text { Schuman (2002) }\end{array}$ \\
\hline $\begin{array}{l}\text { Northern mixed-grass prairie } \\
\text { Wyoming }\end{array}$ & & 0.30 & $\begin{array}{l}\text { Schuman et al. } \\
\text { (1999) }\end{array}$ \\
\hline $\begin{array}{l}\text { Northern mixed-grass prairie } \\
\text { North Dakota }\end{array}$ & & 0.29 & Frank (2004) \\
\hline \multirow{7}{*}{$\begin{array}{l}\text { Primarily temperate grasslands } \\
\text { Worldwide }\end{array}$} & Fertilization & 0.30 & \multirow{7}{*}{$\begin{array}{l}\text { Conant et al. } \\
\text { (2001) }\end{array}$} \\
\hline & Improved grazing & 0.35 & \\
\hline & Conversion from arable to permanent grassland & 1.01 & \\
\hline & Conversion from native vegetation to grassland & 0.35 & \\
\hline & Introduction of legumes & 0.75 & \\
\hline & Earthworm introduction & 2.35 & \\
\hline & Improved grass species & 3.04 & \\
\hline Cool temperate grassland - USA & Conversion from arable land to permanent pasture & 0.27 & Post \& Kwon (2000) \\
\hline \multirow{7}{*}{$\begin{array}{c}\text { Managed grassland } \\
\text { (simple statistical model) } \\
\text { France }\end{array}$} & Reduction in N-fertilizer inputs in intensive leys & 0.3 & \multirow{7}{*}{$\begin{array}{l}\text { Soussana et al. } \\
\quad(2006)\end{array}$} \\
\hline & Conversion of arable land to grass/legume & $0.3-0.5$ & \\
\hline & Intensification of permanent grassland & 0.2 & \\
\hline & Intensification of nutrient-poor grassland & -0.9 to -1.1 & \\
\hline & Permanent grassland to medium-duration leys & -0.2 & \\
\hline & Increasing duration of leys & $0.2-0.5$ & \\
\hline & Short-duration leys to permanent grassland & $0.3-0.4$ & \\
\hline Perennial grassland - Texas & Converted from arable to grassland for 6-60 yr & 0.45 & Potter et al. (1999) \\
\hline $\begin{array}{l}\text { Prairie grazing lands (11.5 Mha) } \\
\text { Canada }\end{array}$ & $\begin{array}{l}\text { Improved management practices (grazing, reduced } \\
\text { stocking intensity and N fertilization) }\end{array}$ & 0.04 & Lynch et al. 2005 \\
\hline Grasslands - Argentina & $\begin{array}{c}\text { Impact of } 370 \text { years of livestock grazing (from early } \\
\text { European colonization to present) }\end{array}$ & -2.2 & Piňeiro et al. (2006) \\
\hline $\begin{array}{c}\text { Northern mixed-grass prairie South } \\
\text { Dakota }\end{array}$ & Legume interseeding & $0.33-1.56$ & $\begin{array}{l}\text { Mortenson et al. } \\
\text { (2004) }\end{array}$ \\
\hline Tallgrass Prairie - Kansas & \multirow{3}{*}{ Nitrogen fertilization } & 1.6 & Rice (2000) \\
\hline $\begin{array}{l}\text { Conservation Reserve Program } \\
\text { Wyoming }\end{array}$ & & $0.41-1.16$ & Reeder et al. (1998) \\
\hline $\begin{array}{l}\text { Conservation Reserve Program } \\
\text { Saskatchewan }\end{array}$ & & $5.4-9.3$ & Nyborg et al. (1994) \\
\hline
\end{tabular}




\begin{tabular}{|c|c|c|c|}
\hline Grassland type - Location & Management Practice & $\begin{array}{c}\text { CSeq. rate } \\
\left(M g C h a^{-1} y r^{-1}\right)\end{array}$ & Citation \\
\hline $\begin{array}{c}\text { Conservation Reserve Program } \\
\text { Texas, Kansas, Nebraska }\end{array}$ & \multirow[t]{4}{*}{ Restoration } & $0.8-1.1$ & Gebhart et al. (1994) \\
\hline $\begin{array}{l}\text { Oklahoma/ Southern mixed-grass } \\
\text { prairie }\end{array}$ & & $\begin{array}{c}65 \% \downarrow \text { in SOC in } 0- \\
10 \mathrm{~cm} \text { with heavy } \\
\text { grazing }\end{array}$ & $\begin{array}{l}\text { Fuhlendorf et al. } \\
\text { (2002) }\end{array}$ \\
\hline \multirow[t]{2}{*}{ Sudan/ Southern mixed-grass prairie } & & $\begin{array}{c}80 \% \text { of native } \\
\text { rangeland in } 100 \mathrm{yr}\end{array}$ & $\begin{array}{c}\text { Olsson \& Ardö } \\
(2002)\end{array}$ \\
\hline & & MMTC $\mathrm{yr}^{-1}$ & \\
\hline \multirow[t]{6}{*}{ U.S. grazing land } & Grazed grassland & 29.5 to 110 & \multirow[t]{6}{*}{ Follett et al. (2001) } \\
\hline & Land conversion and restoration & 17.6 to 45.7 & \\
\hline & Low-input grassland & -4.1 to 13.9 & \\
\hline & 'Improved management' and intensification & 16.0 to 50.4 & \\
\hline & Emissions from grazing lands & -12 to -19.5 & \\
\hline & Net gain for US total grazing lands & 17.5 to 90.5 & \\
\hline $\begin{array}{l}\text { Worldwide grassland and Savanna } \\
\qquad(2,400 \mathrm{Mha})\end{array}$ & Present $\mathrm{C}$ sink & 500 & $\begin{array}{c}\text { Scurlock \& Hall } \\
\text { (1998) }\end{array}$ \\
\hline
\end{tabular}




\section{Impact of grazing on rangeland soil carbon pool}

The impact of grazing management on the soil biogeochemical processes that regulate rangeland carbon dynamics is not well understood due to heterogeneity in grassland types. Milchunas and Laurenroth (1993) evaluated 34 data sets to compare soil carbon of grazed and protected areas and found that about $40 \%$ of these results indicate an increase in soil carbon due to grazing and about $60 \%$ showed a decrease or no response to grazing.

The impact of grazing on ecosystem processes is influenced by:

- the extent of the removal of photosynthetic biomass (defoliation), which is determined in part by grazing intensity;

- treading and trampling; and

- fecal and urine depositions (Heitschmidt et al. 2004).

The extent of defoliation depends on plant morphology, growth stages, and the availability of water and nutrients. Repeated grazing reduces plant growth and productivity, whereas light-tomoderate levels cause suppression of growth with occasional growth enhancement (Briske and Richards 1995). Selective defoliation modifies species composition, which often results in low productivity and undesirable plant compositions. Trampling and treading compact the soil surface increasing the soil bulk density while hoof action deteriorates soil aggregate stability.

Unfavorable changes in soil physical properties may cause a decline in water infiltration and root growth. The addition of nutrients in the form of fecal and urine influences the soil biogeochemical processes. Altogether, grazing has the potential to influence rangeland carbon dynamics by altering plant litter chemistry (Milchunas and Laurenroth 1993; Barger et al. 2004), plant biomass allocation patterns (Binodini et al. 1998), litter production, and the spatial distribution of nutrients (Potvin and Harrison 1984; Day and Delting 1990; Frank and Evans 1997). Depending on the intensity, grazing pressure may slow decomposition rates by decreasing plant litter carbon to nitrogen $(\mathrm{C}: \mathrm{N})$ ratio, or due to decreased standing biomass, may accelerate the decomposition by increasing soil temperature (Welker et al. 2004).

Despite the above mentioned grazing impact on rangeland carbon dynamics, results showed a wide variation ranging from positive (Schuman et al 1999) to negative (Dormar and Wilms 1998) to no response (Reeder et al. 1998). Gill (2007) evaluated the influence of 90 years of protection from grazing on carbon dynamics in subalpine rangeland and reported that livestock grazing had no significant impacts on total soil carbon or particulate organic matter, but active soil carbon content increased. The loss of carbon from the active carbon pool was higher in grazed plots ( $4.6 \%$ of total $\mathrm{C}$ ) than in ungrazed plots $(3.3 \%$ of total $\mathrm{C})$. These results imply that grazing may convert the relatively recalcitrant carbon pool into easily mineralizable carbon fraction. The exclusion of grazing caused an increase in annual forbs and grasses lacking in dense fibrous rooting system conducive to soil organic matter formation and accumulation (Reeder and Schuman 2002).

The intensity of grazing is a major factor in controlling rangeland SOC dynamics. In pastures of Virginia, USA, Conant et al. (2003) found that soil organic carbon averaged $8.4 \mathrm{Mg} \mathrm{C}^{-1}$ more under intensive management or short rotation grazing than extensively grazed or hayed sites. Naeth et al. (1991) observed a negative impact on soil organic matter with heavy intensity or early season grazing, as compared to light intensity or late season grazing in the grasslands of Alberta, Canada. Heavy grazing resulted in significant reductions in height of standing and fallen 
litter, and a decrease in live vegetative cover and organic matter mass. They also reported that large particle size organic matter was associated with ungrazed treatments; whereas, medium or small particle sized organic matter occurred in grazed treatments. Johnston et al. (1970) reported that heavy grazing of fescue grassland range in Alberta changed the color of the Ah horizon (a soil layer enriched with organic matter) from black to dark brown, reduced the percent organic matter, increased soil temperature, but decreased percent soil moisture. Change in organic matter content due to heavy grazing is related to the change in soil physical environment and quantity of organic matter input.

Some studies reported a similar SOC content or no response to heavy grazing. Frank et al. (1995) reported that heavy grazing did not reduce SOC compared with exclosures or control sites, but moderately grazed pasture contained $17 \%$ less SOC than the control within $106.7 \mathrm{~cm}$ depth in the mixed prairie of North Dakota. Preservation of SOC in heavy grazed sites was equal to the exclosures, which was likely due to an increase in blue grama, a species with a dense shallow root system. Heavy intensity grazed land can be characterized by bare ground or dominated by warm-season grasses, forbs, and lichens, whereas light grazing is covered by litter, western wheatgrass and total cool-season graminoids. Manley et al. (1997) found that heavy grazing increased the percent of above-ground biomass contributed by forbs and decreased western wheat grass contribution.

Moreover, Smoliak et al. (1972) observed a higher value in total carbon and other SOC fractions due to heavy grazing compared to light or no grazing. They attributed the outcomes to alteration in the amount of and kind of roots, due to changes in species composition and the increased amount of manure deposited by sheep. High intensity grazing replaced the deeper rooted species with a shallow-rooted one in the arid environment. Reeder and Schuman (2002) reported significantly higher SOC in grazed pastures compared to non-grazed exclosures and in the case of short grass steppe, higher SOC was only observed within heavy intensity grazing in semiarid grasslands. Grazing at light to moderate stocking rates resulted in stable, diverse plant communities dominated by forage grasses with dense, fibrous rooting systems favorable for building up SOC. Grazing management practices that encourage forage production also have the potential to increase soil organic matter (Conant et al. 2001).

Consequences of increasing atmospheric $\mathrm{CO}_{2}$ concentration can affect rangeland carbon storage by accelerating the photosynthesis rate, which increases biomass production, and lowers the decomposition rate (Schuman et al. 2008). An 8 year old $\mathrm{CO}_{2}$ enrichment study in tall grass prairie revealed that the soil system sequestered an additional $59 \mathrm{~g} \mathrm{C} \mathrm{m}^{-2} \mathrm{yr}^{-1}$ due to increased above and belowground production and resulted in higher SOC. The extent of increased $\mathrm{CO}_{2}$ sequestration potential of rangeland depends on the response of plant communities to elevated $\mathrm{CO}_{2}$. Grass species having higher leaf area than their competitor, will become increasingly dominant under elevated $\mathrm{CO}_{2}$ concentration (Teyssonnneyre et al. 2002).

Dominance of $\mathrm{C}_{3}$ (cold season) species over $\mathrm{C}_{4}$ (warm season) species is another probable consequence of increased $\mathrm{CO}_{2}$ concentration (Soussana and Lüscher 2007). Warm-season $\left(\mathrm{C}_{4}\right)$ grasses are less nutritious than $\mathrm{C}_{3}$ grasses in terms of crude protein content and higher $\mathrm{C}: \mathrm{N}$ ratio. Changes of grazer food quality in terms of fine scale (crude protein concentration and C: $\mathrm{N}$ ratio) and coarse scale $\left(\mathrm{C}_{3}\right.$ species vs. $\mathrm{C}_{4}$ species $)$ may be expected due to elevated $\mathrm{CO}_{2}$ concentrations. The three main issues in considering the fate of rangeland in a high atmospheric $\mathrm{CO}_{2}$ concentrations, are 
- changes in production and quality of herbage;

- changes in the global environment such as rising temperatures, changing precipitation and rising $\mathrm{CO}_{2}$ concentrations will become determinant factors in plant community diversity and loss of production; and

- the impact of extreme climatic conditions e.g. heat waves and droughts on net carbon exchange in terrestrial ecosystem (Ciais et al. 2005; Soussana and Lüscher 2007).

The preservation of rangeland carbon stock in an altered climate with a high temporal variability and elevated $\mathrm{CO}_{2}$ concentrations which may saturate SOC sink, will be the most sensitive issue in the future. 


\section{4. $\quad$ Rangeland Research Methods \& Activities}

To develop a better understanding of the influences of management and climate on terrestrial carbon sequestration in rangelands in the Great Plains, the Big Sky Carbon Sequestration Partnership (BSCSP) commissioned research on selected sites at the High Plains Grasslands Research Station (HPGRS). Schuman et al. (1999) initiated research on a northern mixed grass rangeland site in 1993 and found that grazing significantly increased SOC in the upper $30 \mathrm{~cm}$ of pastures grazed all season at light- and heavy stocking rates, as compared to non-grazed exclosures. Sampling protocol, experimental design, and laboratory methods are described by Schuman et al. (1999). They estimated that over 11 years of grazing, these pastures sequestered carbon at the rate of $0.30 \mathrm{MgC} \mathrm{ha}^{-1} \mathrm{yr}^{-1}$. Schuman's research was continued under this project, and sampling was carried out in 2003 to assess the effect of several drought years during the period 1993-2002. Re-sampling of the permanent transects established by Hart et al. (1988) in 1983 and sampled in 1993 showed that drought can significantly impact rangeland SOC levels; hence, carbon sequestration. SOC in the $0-30 \mathrm{~cm}$ soil depth of the continuous, heavily grazed $(\mathrm{CH})$ and non-grazed $(\mathrm{EX})$ was significantly lower than that of the continuous, lightly grazed (CL) treatment.

Table 2 shows the levels of SOC present in the various soil depths in 1993 and 2003 of the northern mixed grass rangeland site near Cheyenne, Wyoming. Significant below average precipitation in 7 of 10 years (Figure 1) resulted in a loss of SOC from the $\mathrm{CH}$ and EX treatments. During the 21 years of grazing on these pastures, plant community composition changes and productivity occurred that help to explain the loss in SOC observed during these drought years. In the past 21 years, plant productivity in the heavily grazed pastures has declined by nearly 50\% compared to the EX and CL. Even more important is the fact that the $\mathrm{CH}$ has become dominated by $\mathrm{C}_{4}$ grasses (predominately blue grama) compared to the other two treatments that are dominated by $\mathrm{C}_{3}$ grasses (western wheatgrass).

Table 2: Soil organic carbon mass in the non-grazed (EX), continuous, lightly grazed (CL), and continuous, heavily grazed $(\mathrm{CH})$ pastures at the High Plains Grasslands Research Station, Cheyenne, WY in 1993 and 2003 (Modified from Ingram et al. 2008).

\begin{tabular}{|c|c|c|c|c|c|c|}
\hline \multirow{2}{*}{$\begin{array}{l}\text { Soil depth } \\
\quad(\mathrm{cm})\end{array}$} & \multicolumn{3}{|c|}{$1993 \dagger$} & \multicolumn{3}{|c|}{2003} \\
\hline & EX & $\mathrm{CL}$ & $\mathrm{CH}$ & EX & CL & $\mathrm{CH}$ \\
\hline SOC & & & & $(\mathrm{kg}$ & & \\
\hline $0-15$ & $28,163^{b}$ & $35,141^{\mathrm{a}}$ & $35,950^{\mathrm{aA}}$ & $27,296^{\mathrm{a}}(-3.1)$ & $31,961^{\mathrm{b}}(-9.0)$ & $25,971^{\mathrm{aB}}(-27.8)$ \\
\hline $0-30$ & $47,924^{\mathrm{b}}$ & $57,988^{\mathrm{a}}$ & $58,298^{\mathrm{aA}}$ & $47,293^{\mathrm{a}}(-1.3)$ & $54,193^{\mathrm{b}}(-6.5)$ & $42,521^{\mathrm{aB}}(-27.1)$ \\
\hline $0-60$ & $88,147^{b}$ & $91,936^{b}$ & $101,268^{\mathrm{aA}}$ & $80,456^{\mathrm{a}}(-8.7)$ & $92,471^{\mathrm{b}}(+0.6)$ & $70,526^{\mathrm{aB}}(-30.4)$ \\
\hline
\end{tabular}

Means within a soil depth and year with different lowercase letters are significantly different at $\mathrm{P} \leq 0.10$. Means within a soil depth across years with different uppercase letters significantly different at $\mathrm{P} \leq 0.10$. 


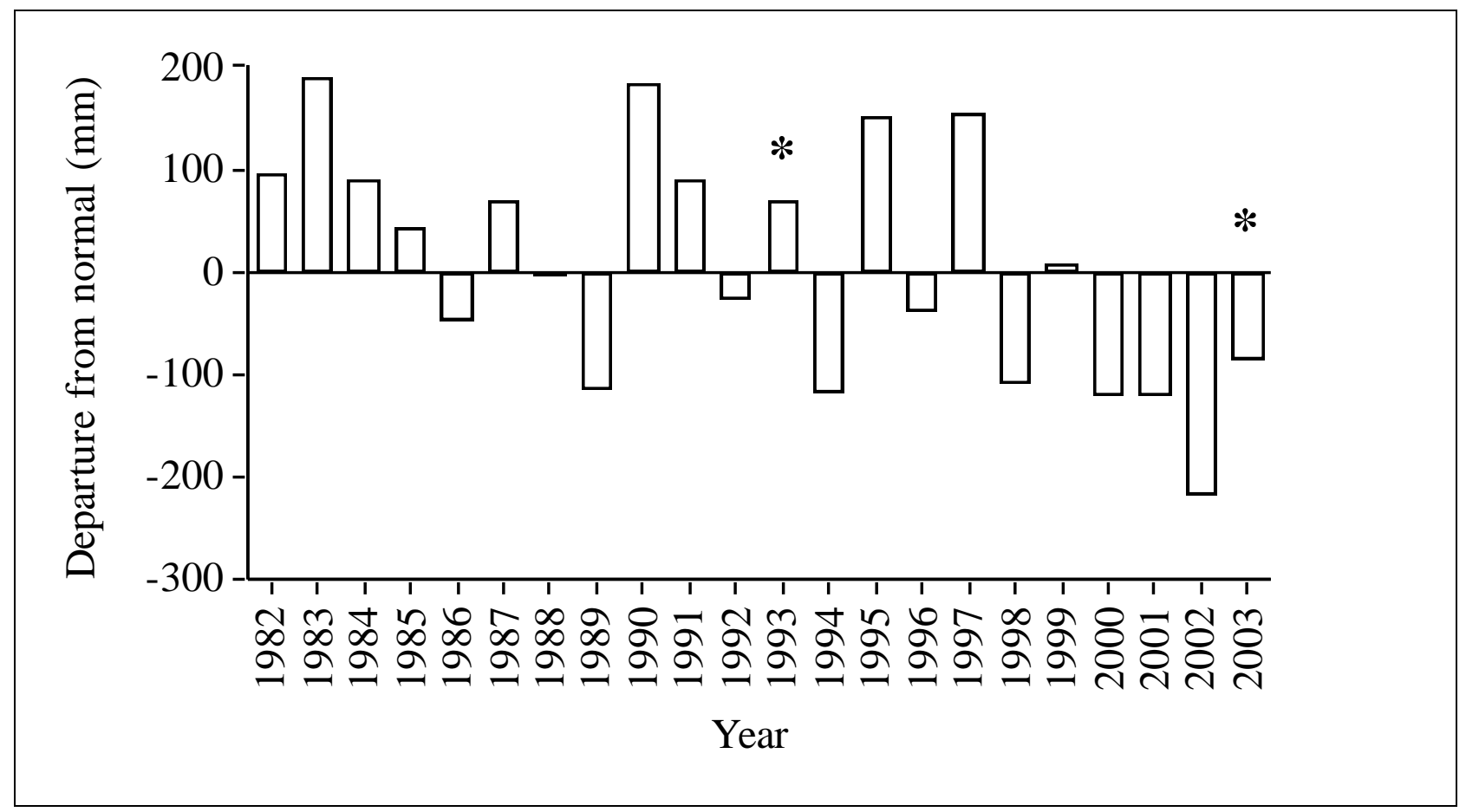

Figure 1: Departure from the long-term (1982-2003) mean annual precipitation (424 mm) at the HPGRS, Cheyenne, WY. The study was initiated in 1982 and sampled in 1993 and 2003 (indicated by the asterisks) (Ingram et al. 2008).

A significant reduction in aboveground biomass in the $\mathrm{CH}$ resulted in lower potential carbon inputs from both above- and belowground litter production (Schuman et al. 1999). Potential root carbon inputs also changed, due to a shift in plant community composition. About $56 \%$ of western wheatgrass root biomass occurs in the top $15 \mathrm{~cm}$ and $86 \%$ in the top $60 \mathrm{~cm}$ of the soil profile (Weaver and Darland 1949). Needle and thread $\left(\mathrm{C}_{3}\right)$ roots are also predominately found in the upper 45 to $90 \mathrm{~cm}$ (Coupland and Johnson 1965). However, 83\% of blue grama roots are found in the surface $15 \mathrm{~cm}$ of the soil with approximately $92 \%$ of their roots being in the surface $30 \mathrm{~cm}$ (Weaver and Darland 1949). The fact that the abundance of blue grama roots are in the surface $30 \mathrm{~cm}$ of the soil allows this species to take advantage of the small precipitation events that are common in this environment, and they deposit a greater amount of their $\mathrm{C}$ belowground (Coupland and Johnson 1965). With blue grama, the predominance of shallow roots make them more vulnerable to decomposition and oxidation and eventual loss to the atmosphere as $\mathrm{CO}_{2}$ and $\mathrm{CH}_{4}$. Bare ground in the $\mathrm{CH}$ treatment also increased by $50-90 \%$ relative to the $\mathrm{CL}$ and EX treatments enabling the potential loss of carbon from the soil via wind and water erosion (Neff 2005).

Changes in the quantity, quality and location of the carbon seem to be important factors in regulating carbon pools in grazed ecosystems (Ingram et al. 2008). These findings are supported by recent research that shows that climate change (temperature and precipitation) can be responsible for significant SOC losses (Bellamy et al. 2005). Soil temperature data collected from an ungrazed area near the study site showed a general increase in temperature at both the 38 and $102 \mathrm{~mm}$ soil depth (data not shown) during the study period 1982-2003. The flux of carbon from the soil to the atmosphere during periods of low precipitation and/or drought in comparable 
ecosystems has been documented by others (Meyers 2001; Frank 2004; Hunt et al. 2004; Morgan et al. 2004; Svejcar et al. 2008).

To further evaluate the long-term effects of livestock grazing and short-term average precipitation effects on SOC, we re-sampled the northern mixed grass rangeland site at the HPGRS in the spring of 2006 (Schuman et al. 2007). Precipitation in 2003 and 2004 were slightly below the long-term average, and 2005 precipitation was above the long-term average. SOC in the $30 \mathrm{~cm}$ soil surface showed no differences between treatments in 2006. The CL and $\mathrm{CH}$ grazing treatments showed a slight but significant decrease in SOC in 2006 compared to 2003; while the EX showed no change during that time. We believe that during the time period 2003 to 2006, the climatic conditions may have overridden management effects on SOC due to the ecological lag of the severe drought of 2002. Conical multivariate analysis of the microbial community data indicates that the structure of the microbial communities was statistically different among the grazing treatments (Figure 2). If we assume the CL grazing treatment is more typical of the grazing that occurred on these rangelands prior to settlement, the $\mathrm{EX}$ and $\mathrm{CH}$ appear to have shifted away from the CL treatment. The microbial biomass, microbial respiration and $\mathrm{N}$-mineralization rates also responded similarly, $\mathrm{CL}>\mathrm{EX}>\mathrm{CH}$ (Ingram et al. 2008).

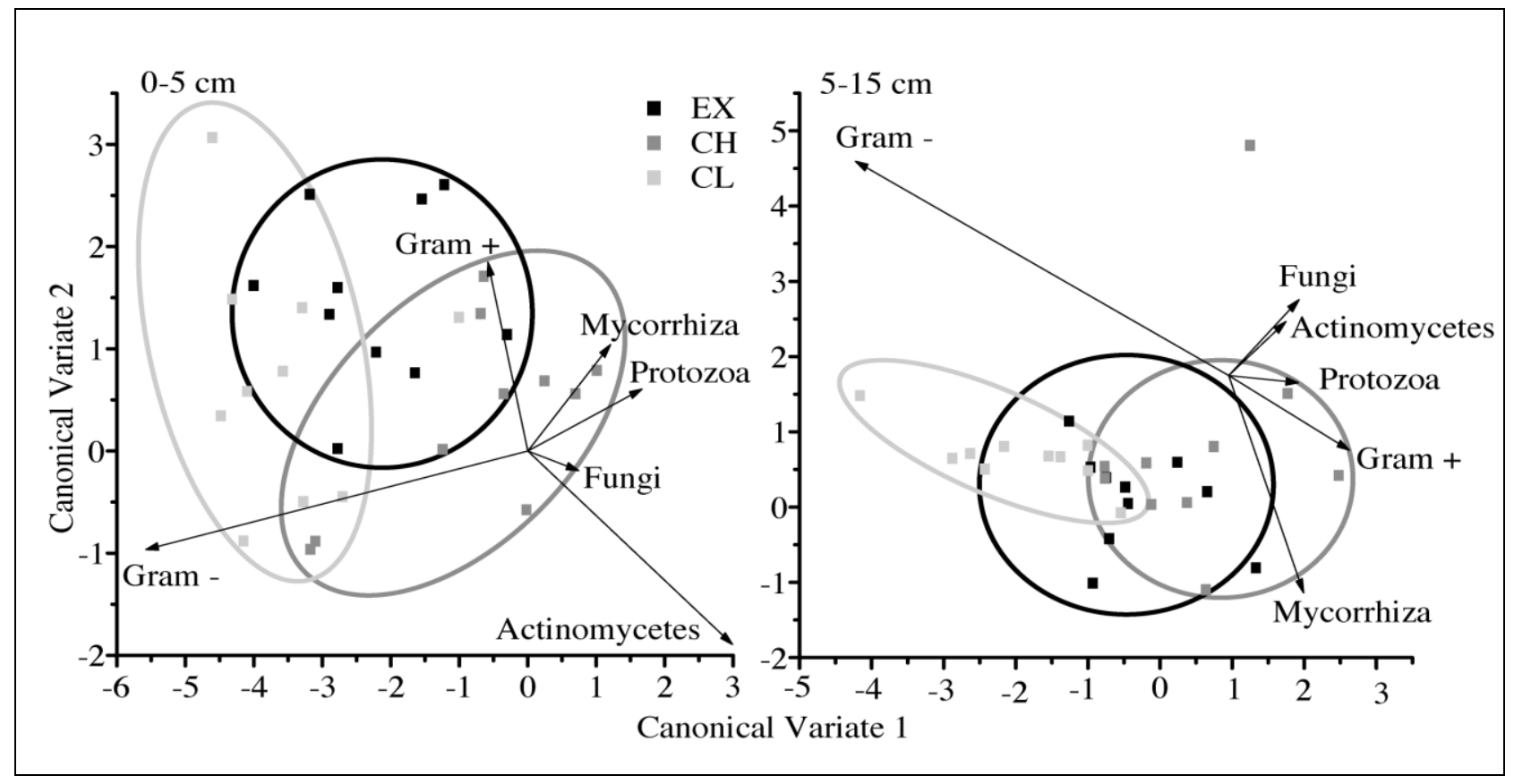

Figure 2: Canonical multivariate analysis for microbial groups as determined by phospolipid fatty acid analysis (PFLA) for the 0-5 and 5-15 cm depth increments from soils in non-grazed (EX), continuously, lightly grazed (CL), and continuously, heavily grazed $(\mathrm{CH})$ pastures at the High Plains Grasslands Research Station, Cheyenne, WY. Ellipses were hand drawn to indicate grazing treatment groupings (Schuman et al. 2007).

Researchers evaluated HPGRS SOC dynamics in CL and CH grazed sites and the 60 year old EX (Ganjegunte et al. 2005). They found that within surface soils $(0-5 \mathrm{~cm})$, the SOC and nitrogen 
contents were significantly greater in CL (SOC $-2.57 \%$ and soil total nitrogen [SN] - 0.23\%) than $\mathrm{CH}$ (SOC - 1.98\% and SN - 0.17\%) or EX (SOC - 2.09\% and SN - 0.18\%). Significant lignin (cupric oxide $[\mathrm{CuO}]$ analysis) contents (e.g., Vanillyl + Syringyl + Cinnamyl compounds - VSC) were noted in EX (429 $\mathrm{mg} \mathrm{kg}^{-1}$ soil) than CL (314 $\mathrm{mg} \mathrm{kg}^{-1}$ soil) and CH (294 mg kg-1 soil) soils. The $\mathrm{CuO}$ oxidation of humic (HA) and fulvic (FA) acids indicated that HA under CL contained significantly greater $\mathrm{V}, \mathrm{S}$, and total lignin than that under $\mathrm{CH}$ or $\mathrm{EX}$, whereas FA extracted from $\mathrm{CH}$ contained significantly greater $\mathrm{V}$ and $\mathrm{C}$ than that extracted from $\mathrm{CL}$ and $\mathrm{EX}$. The ${ }^{13} \mathrm{C}$ NMR spectra of HA did not vary significantly among the three grazing treatments nor did the FA spectra. However, overall the HA spectra had significantly greater alkyl, methoxyl, and aromatic $\mathrm{C}$ than FA, and the FA spectra had significantly greater $\mathrm{O}$-alkyl and di-O-alkyl $\mathrm{C}$ than $\mathrm{HA}$, suggesting HA is more recalcitrant and aromatic than FA. The $\delta^{13} \mathrm{C}$ and $\delta^{15} \mathrm{~N}$ values for humic or fulvic acid did not differ significantly among grazing treatments; however, the overall $\delta^{15} \mathrm{~N}$ value for HA (+2.9) was significantly lower than that for FA (+4.6), indicating that nitrogen in HA is not readily available to plants. These results suggest that there are beneficial effects of light grazing compared to heavy grazing and non-grazing with respect to increased SOC and nitrogen contents. Stimulation of aboveground vegetation growth, better incorporation of aboveground biomass, and increased decomposition rates of plant residues occurred within the CL grazing and increased SOC contents.

To further assess the effects of climatic and land management effects on soil carbon sequestration, Derner and Schuman (2007) reviewed the literature to correlate carbon sequestration with precipitation and management practices. No statistical relationship was found between length of grazing practice and change in SOC. The general trend suggested a decrease in carbon sequestration with longevity of the grazing practice across stocking rate (Figure 3 ). This trend is consistent with the understanding that the ecosystem will reach a 'steady state,' and changes in inputs or management would be required to sequester additional carbon (Conant et al. 2001, 2003; Swift 2001). Derner and Schuman (2007) suggest that carbon sequestration would stop after 80-85 years with a grazing practice. Mortenson et al. (2004) suggested that a 'steady state' was reached after about 30-35 years after interseeding a legume into native rangelands. The effects of precipitation gradient on rangeland carbon storage in the 0-30 cm soil depth showed a general increase with increasing precipitation (Derner and Schuman 2007). Comparisons of grazed vs. nongrazed pastures revealed a threshold from positive to negative sequestration occurs at $440 \mathrm{~mm}$ when assessing the $0-10 \mathrm{~cm}$ soil depth, and at $600 \mathrm{~mm}$ precipitation when assessing the 0-30 soil depth (Figure 4). Above these precipitation levels it appears that carbon sequestration in rangelands decreases. These evaluations of precipitation effects on carbon sequestration agree with those observations of Sims et al. (1978) and Sala et al. (1988) in identifying the 370 to $400 \mathrm{~mm}$ precipitation range as a transition where aboveground ecosystem response to grazing occurs. 


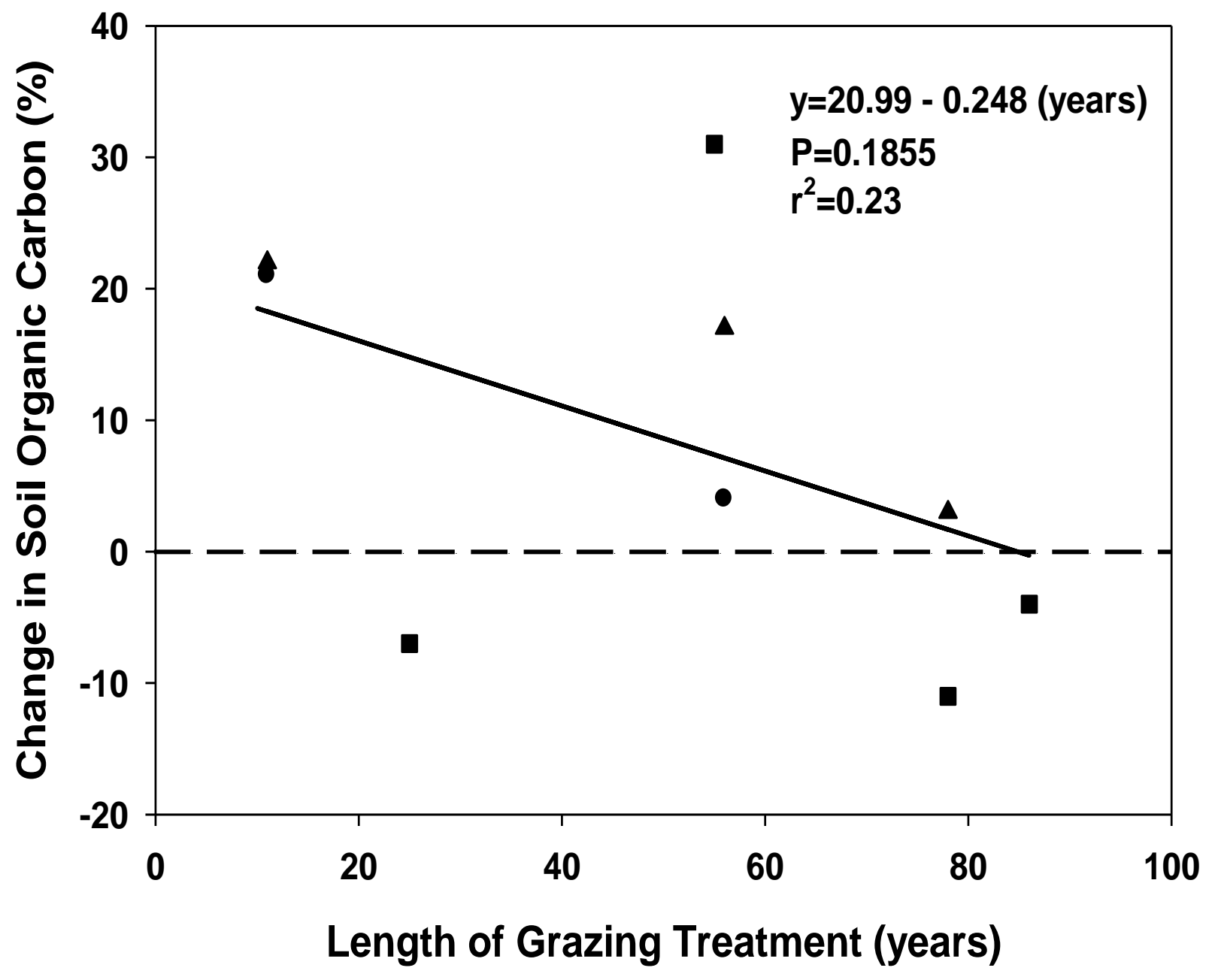

- $\quad 0-30 \mathrm{~cm}$ : light grazing

- 0-30 cm: moderate grazing

$\triangle \quad 0-30 \mathrm{~cm}$ : heavy grazing 0-30 cm: regession line

Figure 3: Change (grazed vs. non-grazed, \%) in soil organic carbon with respect to length of grazing treatment in North American Great Plains (data is from Frank et al. 1995; Schuman et al. 1999; Reeder and Schuman 2002; Derner et al. 2006) (From Derner and Schuman 2007) 


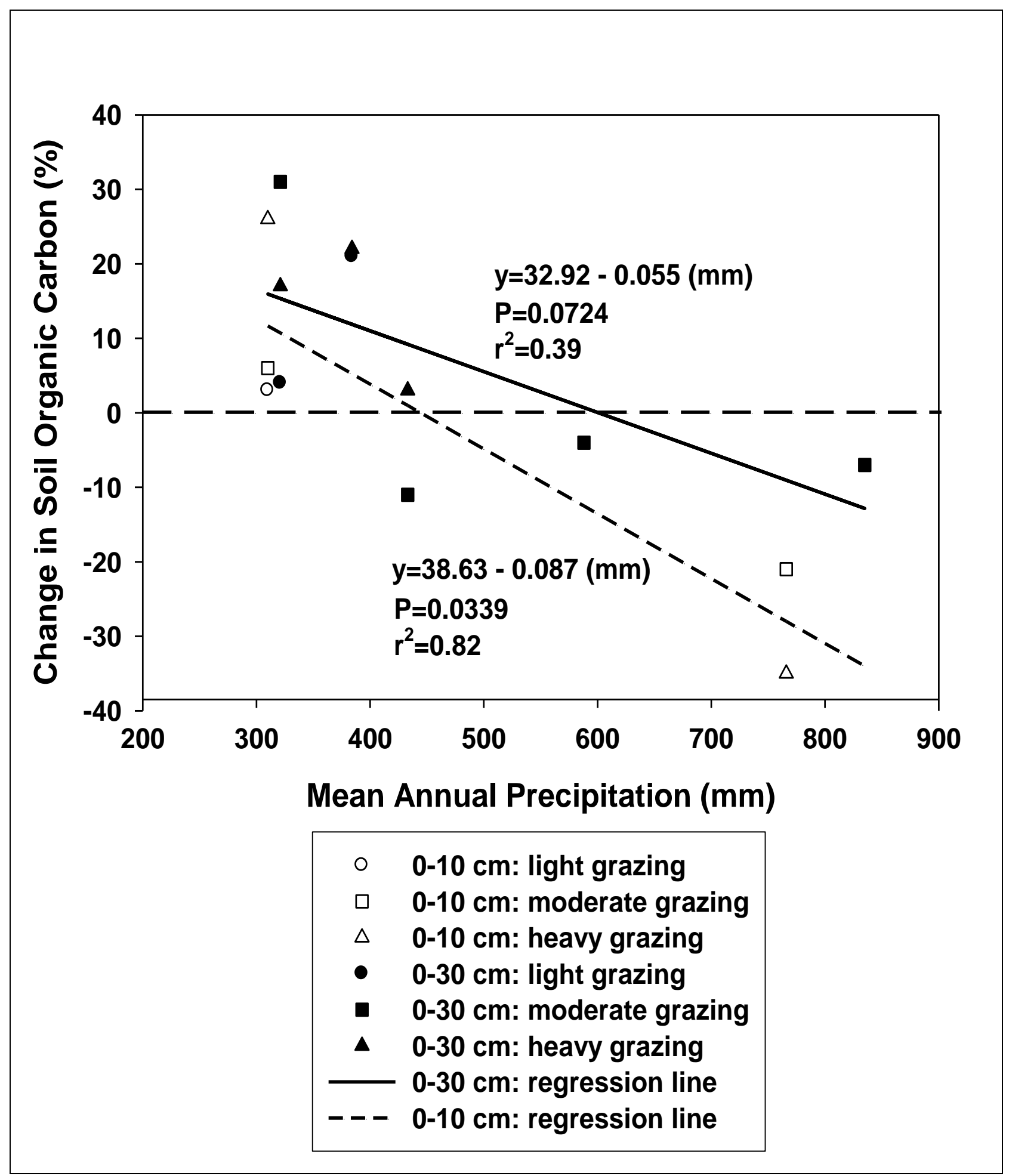

Figure 4: Change (grazed vs. non-grazed, \%) in soil organic carbon change with mean annual precipitation (MAP) with grazing in North American Great Plains (0-10 cm data is from Smoliak et al. 1972 and Fuhlendorf et al. 2002; 0-30 cm data is from Frank et al. 1995; Schuman et al. 1999; Reeder and Schuman 2002; Derner et al. 2006) (From Derner and Schuman 2007) 
Recent efforts by a scientific advisory panel to the Chicago Climate Exchange (http://www.chicagoclimatex.com/) resulted in a Rangeland Soil Carbon Offset Program. Drs.' Justin D. Derner and Gerald E. Schuman were invited to serve on that advisory panel, which developed the protocol being used by the Chicago Climate Exchange to buy carbon offset credits on rangelands in the Great Plains and Northwestern rangelands. Their participation greatly enhances the efforts of this overall research project. The map in Figure 5 shows the Land Resource Regions for which these protocol were developed and the relative carbon sequestration rates accepted by the Chicago Climate Exchange. For greater detail on this subject, see the above mentioned web site. Sagebrush-grasslands were not included in this overall effort, because scientific data is not available to determine or establish carbon sequestration rates on those ecosystems. This is an area of research in this specific rangeland ecosystem that merits attention.

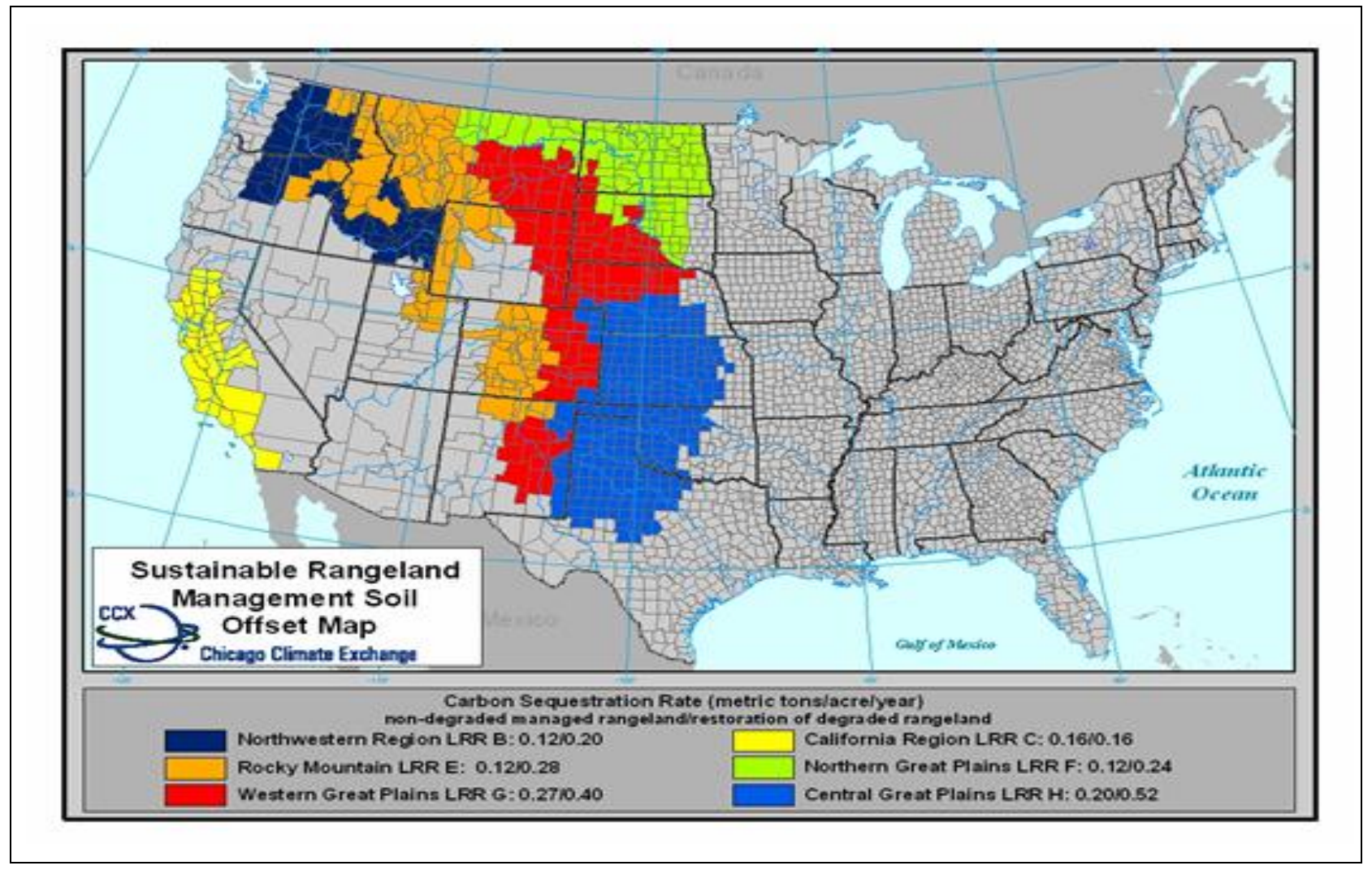

Figure 5: Land Resource Regions and their relative carbon sequestration rates according to the Chicago Climate Exchange 


\section{Conclusion}

Rangelands cover about half of the world's terrestrial area (47\%). Due to the vast area, rangelands may play an important role in soil carbon sequestration. The purpose of this task was to assess the carbon sequestration potential of rangelands, and identify management practices that affect sequestration levels.

Researchers conducted a literature review to identify sustainably management practices that conserve existing rangeland carbon pools, as well as increase or restore carbon sequestration potentials for this type of ecosystem. They identified several practices that have been shown to impact carbon sequestration rates on rangelands. The rates range from -2.2 to $9.3 \mathrm{Mg} \mathrm{C} \mathrm{ha}^{-1} \mathrm{yr}^{-1}$, but most practices sequester less than $1 \mathrm{Mg} \mathrm{C} \mathrm{ha}^{-1} \mathrm{yr}^{-1}$.

The research team also reviewed the impact of grazing management on rangeland carbon dynamics, which are not well understood due to heterogeneity in grassland types. A literature review on the impact of grazing showed a wide variation of results, ranging from positive to negative to no response. On further review, the intensity of grazing appears to be a major factor in controlling rangeland soil organic carbon (SOC) dynamics. Other factors that will impact future sequestration potential include:

- changes in production and quality of herbage;

- changes in the global environment such as rising temperatures, changing precipitation and rising $\mathrm{CO}_{2}$ concentrations; and

- extreme climatic conditions such as heat waves and droughts.

To develop a better understanding of the influences of management and climate on terrestrial carbon sequestration in rangelands in the Great Plains, BSCSP commissioned research on selected sites at the High Plains Grasslands Research Station (HPGRS). In 2003, researchers conducted sampling to assess the effect of several drought years during the period 1993-2002. Results suggested that drought can significantly impact rangeland SOC levels, and therefore, carbon sequestration. Resampling was conducted in 2006; results again suggested that climatic conditions may have overridden management effects on SOC due to the ecological lag of the severe drought of 2002.

Analysis of grazing practices during this research effort suggested that there are beneficial effects of light grazing compared to heavy grazing and non-grazing with respect to increased SOC and nitrogen contents. In general, carbon storage in rangelands also increases with increased precipitation, although researchers identified threshold levels of precipitation where sequestration begins to decrease.

\section{$5.1 \quad$ Example of a Management Practice for Carbon Sequestration}

Based on the findings of the research in this task, the team developed the following scenario to illustrate the potential impact of implementing management practices that may increase carbon sequestration.

A rancher decides to implement a prescribed grazing best management practice (BMP) on an area of rangeland. Watering facilities are added to increase the amount of area available for grazing. Fences are installed to facilitate rotational grazing, which will improve the health and density of vegetation suitable for grazing by livestock and big game. Within 10 years, the amount of carbon sequestered averages approximately $0.27 \mathrm{Mg} \mathrm{C} \mathrm{ha}^{-1} \mathrm{yr}^{-1}$. Assuming the value 
of the sequestered carbon is $\$ 4.00 \mathrm{Mg}^{-1}$, this equates to a value of $\$ 1.08 \mathrm{ha}^{-1} \mathrm{yr}^{-1}$. The number of marketable animals produced and the weight of the animals sent to market increases. Increased costs are incurred to install fences and watering facilities and for the additional labor for rotational grazing. This rancher's beef production increased from about 20 to $30 \mathrm{~kg} \mathrm{ha}^{-1} \mathrm{yr}^{-1}$. The rancher realizes that this change in the operation of the ranch also has the potential to increase the value of the land. It will also improve conditions for fish and wildlife habitat, thus creating the potential for revenue from hunting or fishing activities.

\subsection{Management Practices that Sequester Carbon in Plants and Soils}

Based on the overall findings of this research, management practices that may result in an increased carbon sequestration in plants and soils are summarized in Table 3.

Table 3: Practices that result in a net sequestering of carbon in plants and soils

\begin{tabular}{|c|c|}
\hline GRAZING LAND PRACTICES & $\begin{array}{l}\text { Accumulation } \\
\mathrm{Mg} \mathrm{ha}^{-1} \mathrm{yr}^{-1}\end{array}$ \\
\hline Controlling annual plants & + \\
\hline Seeding areas of low vegetation density with perennial plants & + \\
\hline Improving/maintaining range health to a high level by proper stocking rates ${ }^{1}$ & 0.30 \\
\hline Improving/maintaining range health to a high level by prescribed grazing ${ }^{1}$ & $>0.30$ \\
\hline Rotation grazing & + \\
\hline Facilitating grazing management by developing livestock water facilities and fencing & + \\
\hline Interseeding with legumes $^{2}$ & + \\
\hline Reduce the amount of brush on bush-dominated areas, preferably by mechanical methods & + \\
\hline $\begin{array}{l}\text { Maintain healthy grazing lands by implementing practices suggested by results of periodic } \\
\text { vegetation condition assessments }\end{array}$ & + \\
\hline Planting tree species that produce highest amounts of wood & + \\
\hline Selecting sites for new plantings according to the highest potential for growth rates & + \\
\hline Plant shrubs and trees when reclaiming disturbed areas, such as mines & + \\
\hline Farmstead shelterbelts ${ }^{3}$ & $\begin{array}{l}14 \text { million tons in } 20 \\
\text { years }\end{array}$ \\
\hline Living snow fences ${ }^{3}$ & $\begin{array}{l}192,000 \text { tons per } 1000 \\
\text { miles in } 20 \text { years }\end{array}$ \\
\hline+ Carbon Storage is increased, but research is needed to determine values & \\
\hline
\end{tabular}

1/Eve et al. (2002); ${ }^{2} /$ Mortenson et al. (2004); ${ }^{3} /$ National Agroforestry Center (2001) 


\section{References}

Allen-Diaz, B. 1996. Rangelands in a changing climate: impacts, adaptations, and mitigation. P. 131-158. In R.T. Watson, M.C. Zinyowera, R.H. Moss (eds.). Climate Change 1995. Impacts, Adaptations, and Mitigation of Climate Change: Scientific-Technical Analyses. Published for the Intergovernmental Panel on Climate Change. Cambridge University Press, Cambridge, UK.

Barger, N.N., D.S. Ojima, J. Benlap, S.P. Wang, Y.F. Wang, and Z.Z. Chen. 2004. Changes in plant functional groups, litter quality, and soil carbon and nitrogen mineralization with sheep grazing in an Inner Mongolian grassland. Journal of Range Management. 57:1385-1389.

Bellamy, P.H., P.J. Loveland, R.I. Bradley, R.M. Lark, and G.J.D. Kirk. 2005. Carbon losses from all soils across England and Wales 1978-2003. Nature (London) 437:245-248.

Binodini, M.E., B.D. Patton, and P.E. Nyren. 1998. Grazing intensity and ecosystem processes in a northern mixed-grass prairie, USA. Ecological Applications. 8:469-479.

Briske, D.D., and J.H. Richards. 1995. Plant responses to defoliation: a physiologic, morphologic, and demographic evaluation. P. 635-710. In Wildland Plants: Physiolgical Ecology and Developmental Morphology. Society for Range Management. Denver, CO.

Chadwick, O.A., E.F. Kelly, D.M. Merritts, and R.G. Amundon. 1994. Carbon dioxide consumption during soil development. Biogeochemistry. 24:115-127.

Ciais, P., M. Reichstein, N. Viovy, A. Granier, J. Ogee, V. Allard, M. Aubinet, N. Buchmann, C. Bernhofer, A. Carrara, F. Chevallier, N. De Noblet, A.D. Friend, P. Friedlingstein, T. Grunwald, B. Heinesch, P.Keronen, A. Knohl, G. Krinner, D. Lousatu, G. Manaca, G. Matteucci, F. Miglietta, J.M. Ourcival, D. Papale, K. Pilegaard, S. rambal, G. Seufert, J-F. Soussana, M.J. Sanz, D.E. Schulze, T. Vesala, and R. Valentini. 2005. An unprecedented reduction in the primary productivity of Europe during 2003 caused by heat and drought. Nature. 437:529-532.

Conant, R.T., K. Paustain, and E.T. Elliot. 2001. Grassland management and conversion into grassland: Effects on soil carbon. Ecological Applications 11:343-355.

Conant, R.T., J. Six, and K. Paustian. 2003. Land use effects on soil carbon fractions in the southeastern United States. I. Management-intensive versus extensive grazing. Biology and Fertility of Soils. 38:386-392.

Coupland, R.T. and R.E. Johnson. 1965. Rooting characteristics of native grassland species in Saskatchewan. J. Ecology 53:475-507.

Day, T.A., and J.K. Delting. 1990. Grassland patch dynamics and herbivore grazing preference following urine deposition. Ecology. 71:180-188.

Derner, J.D. and G.E. Schuman. 2007. Carbon sequestration and rangelands: A synthesis of land management and precipitation effects. Journal of Soil and Water Conservation 62:77-85.

Derner, J.D., D.D. Briske, and T.W. Boutton. 1997. Does grazing mediate soil carbon and nitrogen accumulation beneathe $\mathrm{C} 4$ perennial grasses along an environmental gradient: Plant and Soil 191:147-156. 
Derner, J.D., T.W. Boutton, and D.D. Briske. 2006. Grazing and ecosystem carbon storage in the Northe American Great Plains. Plant and Soil 280-77-90.

Dormaar, J.F., and W.D. Wilms. 1998. Effect of forty-four years of grazing on fescue grassland soils. Journal of Range Management. 51:122-126.

Eve, M.D., M. Sperow, K. Howerton, K. Paustian, R.F. Follett. 2002. Predicted Impact of Management Changes on Soil Carbon Stocks for each Agricultural Region of the Conterminous U.S. J. Soil and Water Conservation 57:196-204.

Frank, A.B. 2004. Six years of $\mathrm{CO}_{2}$ flux measurement for moderately grazed mixed-grass prairie. Environmental Management 33:S426-S431

Frank, A.B., D.L. Tanka, L. Hofmann, and R.F. Follett. 1995. Soil carbon and nitrogen on Northern Great Plains grasslands as influenced by long-term grazing. Journal of Range Management. 48:470-474.

Frank, D.A. and R.D. Evans. 1997. Effects of native grazers on grassland $\mathrm{N}$ cycling in Yellowstone National Park. Ecology. 78:2238-2241.

Follett, R.F. 2001. Organic carbon pools in grazing land soils. P. 65-86. In R.F. Follett, J.M. Kimble, R. Lal (eds.). The Potential of U.S. Grazing Lands to Sequester Carbon and Mitigate the Greenhouse Effect. CRC Press, Boca Raton, Fl.

Fuhlendorf, S.D. H. Zhang, T.R. Tunnell, D.M. Engle, A.F. Cross. 2002. Effects of Grazing on Restoration of Southern Mixed Prairie Soils Restoration Ecology 10:401-407.

Ganjegunte, G.K., G.F. Vance, C.M. Preston, G.E. Schuman, L.J. Ingram, P.D. Stahl, and J.M. Welker. 2005. Influence of different grazing management practices on soil organic carbon constituents in a northern mixed-grass prairie. Soil Science Society of America Journal 69:1746-1756.

Gebhart, D.L., H.B. Johnson, H.S. Mayeux, and H.W. Polley. 1994. The CRP increases soil organic carbon. Journal of Soil and Water Conservation 49:488-492.

Gill, R.A. 2007. Influence of 90 years of protection from grazing on plant and soil processes in the subalpine of the Wasatch Plateau, USA. Rangeland Ecology and Management. 60:88-98.

Hart, R.H., M.J. Samuel, P.S. Test, and M.A. Smith. 1988. Cattle, vegetation, and economic responses to grazing systems and grazing pressure. J. Range Management 41:282-286.

Heitschmidt, R.K., L.T. Vermeire, and E.E. Grings. 2004. Is rangeland agriculture sustainable? Journal of Animal Science. 82:E138-E146.

Hunt, J.E., F.M. Kelliher, T.M. McSeveny, D.J. Ross, and D. Whitehead. 2004. Long-term carbon exchange in a sparse, seasonally dry tussock grassland. Glob. Change Biol. 10:17851800.

Ingram, L.J., P.D. Stahl, G.E. Schuman, J.S. Buyer, G.F. Vance, G.K. Ganjegunte, J.M. Welker, and J.D. Derner. 2008. Grazing impacts on soil carbon and microbial communities in a mixed-grass ecosystem. Soil Science Society of America Journal 72:939-948.

Johnston, A., J.F. Dormaar, and S. Smoliak. 1970. Long-term grazing effects on fescue grassland soils. Journal of Range Management. 24:185-188. 
Lal, R. 2001. Soil Erosion and carbon dynamics on grazing land. P. 231-247. In R.F. Follett, J.M. Kimble, R. Lal (eds.). The Potential of U.S. Grazing Lands to Sequester Carbon and Mitigate the Greenhouse Effect. CRC Press, Boca Raton, Fl.

Lynch, D.H., R.D.H. Cohen, A. Fredeen, G. Patterson, and R.C. Martin. 2005. Management of Canadian prairie region grazed grasslands: Soil $\mathrm{C}$ sequestration, livestock productivity and profitability. Canadian Journal of Soil Science 85:183-192.

Manley, J.T., G.E. Schuman, J.D. Reeder, and R.H. Hart. 1995. Rangeland soil carbon and nitrogen responses to grazing. Journal of Soil and Water Conservation. 50:294-298.

Manley, W.A., R.H. Hart, M.J. Samuel, M.A. Smith, J.W. Waggoner Jr., and J.T. Manley. 1997. Vegetation, cattle, and economic responses to grazing strategies and pressures. Journal of Range Management. 50:638-646.

Meyers, T.P. 2001. A comparison of summertime water and $\mathrm{CO}_{2}$ fluxes over rangeland for well watered and drought conditions. Agric. For. Meteorol. 106:205-214.

Milchunas, D.G., and W.K. Laurenroth. 1993. Quantitative effects of grazing on vegetation and soils over a global range of environments. Ecological Monographs. 63:327-366.

Monger, H.D., and J.J. Martinez-Rios. 2001. Inorganic carbon sequestration in grazing lands. P. 87-118. In R.F. Follett, J.M. Kimble, R. Lal (eds.). The Potential of U.S. Grazing Lands to Sequester Carbon and Mitigate the Greenhouse Effect. CRC Press, Boca Raton, Fl.

Morgan, J.A., D.R. LeCain, J.D. Reeder, G.E. Schuman, J.D. Derner, W.K. Lauenroth, W.J. Parton, and I.C. Burke. 2004. Drought and grazing impacts on $\mathrm{CO}_{2}$ fluxes in the Colorado Shortgrasse Steppe. Annual Meeting Abstracts, Portland, OR. 1-6 August 2004. Ecological Society of America, Washington, DC

Mortenson, M.C., G.E. Schuman, and L.J. Ingram. 2004. Carbon sequestration in rangelands interseeded with yellow-flowering alfalfa (Medicago sativa ssp. falcata). Environmental Management 33:S475-S481.

Naeth, M.A., A.W. Bailey, D.J. Pluth, D.S. Chanasyk, and R.T. Hardin. 1991. Grazing impacts on litter and soil organic matter in mixed prairie and fescue grassland ecosystems of Alberta. Journal of Range Management. 44:7-12.

National Agroforestry Center. 2001. Working trees for carbon: Windbreaks in the U.S. USDA, National Agroforestry, Lincoln, NE (Adapted from "Opportunities to increase tree plantings in shelterbelts and the potential impacts of carbon storage and conservation." 1992. J. Brandle, T. Wardle, and G. Branon, Chapter 9, Forests and Global Change, Vol. I. R. N. Sampson and D. Hair (eds.) American Forests.)

Neff, J.C. 2005. Multi-decadal impacts of grazing on soil physical and biogeochemical properties in southeast Utah. Ecological Applications 15:87-95.

Nyborg, M., Solberg, E.D. and Malhi, S.S. 1994. Soil C content under bromegrass increased by $\mathrm{N}$ and S fertilizer applications. Pp. 325-328 In: 31st Annual Alberta Soil Science Workshop Proceedings. Edmonton, Alberta.

Ojima, D.S., B.O. Dirks, E.P. Glenn, C.E. Owensby, and J.O. Scurlock. 1993. Assessment of C budget for grasslands and drylands of the world. Water, Air and Soil Pollution 79:95-109. 
Olsson, L. and J. Ardö. 2002: Soil carbon sequestration in degraded semiarid agro-ecosystems perils and potentials. Ambio 31:471-477.

Piñeiro G., M. Oesterheld, J.M. Paruelo. 2006. Seasonal variation in aboveground production and radiation use efficiency of temperate rangelands estimated through remote sensing. Ecosystems 9: 357-373.

Post, W.M. and K. C. Kwon. 2000. Soil carbon sequestration and land-use change: Processes and potential. Global Change Biology 6:317-328.

Potter, K.N., H.A. Torbert, H.B. Johnson, and C.R. Tischler. 1999. Carbon storage after longterm grass establishment on degraded soils. Soil Science 164:718-725.

Potvin, M.A., and A.T. Harrison. 1984. Vegetation and litter changes of a Nebraska (USA) sandhills prairie protected from grazing. Journal of Range Management. 37:55-58.

Reeder, J.D. and G.E. Schuman. 2002. Influence of livestock grazing on C sequestration in semiarid mixed-grass and short-grass rangelands. Environmental Pollution, 116:457-463.

Reeder, J.D., G.E. Schuman, J.A. Morgan, D.R. LeCain, and R.H. Hart. 1998. Impact of livestock grazing on the carbon and nitrogen balance of a shortgrass steppe. Agronomy Abstracts. American Society of Agronomy, Madison, WI. p.291.

Rice, C.W., 2000. Soil organic $\mathrm{C}$ and $\mathrm{N}$ in rangeland soils under elevated $\mathrm{CO}_{2}$ and land management. In: Proc., Advances in Terrestrial Ecosystem Carbon Inventory, Measurements, and Monitoring. 3-5 October 2000. USDA-ARS, USDA-FS, USDA-NRCS, US Dept. Energy, NASA, and National Council for Air and Stream Improvement, Raleigh, NC, pp. 83.

Sala, O.E., W.J. Parton, L.A. Joyce, and W.K. Lauenroth. 1988. Primary production of the central grassland region of the United States. Ecology 69:40-45.

Schimel, D.S., W.J. Parton, T.G. Kittel, D.S. Ojima, and C.V. Cole. 1990. Grassland biogeochemistry: Links to atmospheric processes. Climate Change 17:13-25.

Schlesinger, W.H. 1995. An overview of the carbon cycle. P. 9-25. In R.Lal, J. Kimble, E. Levine, and B.A. Stewart (eds.). Soil and Global Change. CRC-Lewis Press, Boca Raton, Fl.

Schlesinger, W.H. 1997. Biogeochemistry: An analysis of global change. Academy Press, New York

Schlesinger, W.H., J.F. Reynolds, G.L. Cunningham, L.F. Huenneke, W.M. Jarrell, R.A. Virginia, and W.G. Whitford. 1990. Biological feedbacks in global desertification. Science. 247:1043-1048.

Schuman, G.E., J.E. Herrick, and H.H. Janzen. 2001. The dynamics of soil carbon in rangeland. pp. 267-290. In: R.F. Follett, J.M. Kimble, and R. Lal (eds.) The Potential of U.S. Grazing Lands to Sequester Carbon and Mitigate the Greenhouse Effect. Lewis Publishers, Boca Raton, FL.

Schuman, G.E., L.J. Ingram, P.D. Stahl. J.D. Derner, G.F. Vance and J.A. Morgan. 2008. Influence of management on soil organic carbon dynamics of Northern Mixed-Grass Rangelands. pp. 169-180. In: R. Lal (ed.) Soil Carbon Sequestration and the Greenhouse Effect. Soil Science Society of America Special Publ. \#57, Madison, WI. 
Schuman, G.E., J.D. Reeder, J.T. Manley, R.H. Hart, and W.A. Manley. 1999. Impact of grazing management on the carbon and nitrogen balance of a mixed-grass rangeland. Ecological Applications 9:65-71.

Schuman, G.E., G.F. Vance, J.D. Derner, L.J. Ingram, P.D. Stahl, and A. Chatterjee. 2007. Longterm effects of grazing and climatic conditions on carbon sequesteration and microbial dynamics on rangelands. Soil Science Society of America meeting Abstracts, 4-8 November 2007, New Orleans, LA. Soil Science Society of America, Madison, WI

Scurlock, J.M. and D.O. Hall. 1998. The global carbon sink: A grassland perspective. Global Change Biology 4:229-233.

Sims, P.L., J.S. Singh, and W.K. Lauenroth. 1978. The structure and function often western North American grasslands. I. Abiotic and vegetational characteristics. Journal of Ecology 66:251-285.

Smoliak, S., J.F. Dormaar, and A. Johnston. 1972. Long-term grazing effects on Stipa-Bouteloua prairie soils. Journal of Range Management 25:246-250.

Soussana, J-F., and A. Lüschert. 2007. Temperate grasslands and global atmospheric change: a review. Grass and Forage Science. 62:127-134.

Soussana J.F., P. Loiseau, N. Vuichard, E. Ceschia, J. Balesdent, T. Chevallier, and D. Arrouays. 2006. Carbon cycling and sequestration opportunities in temperate grasslands. Soil Use and Management 20:219-230.

Svejcar, T., R. Angell, J.A. Bradford, W. Dugas, W. Emmerich, A.B. Frank, T. Gilmanov, M. Haferkamp, D.A. Johnson, H. Mayeux, P. Mielnick, J. Morgan, N.Z. Saliendra, G.E. Schuman, P.L. Sims, and K. Snyder. 2008. Carbon Fluxes on North American Rangelands. Rangeland Ecol Manage 61:465-474.

Swift, R.S. 2001. Sequestration of carbon by soil. Soil Science 166:858-871.

Teyssonneryre, F., C. Picon-Cochard, and J-F. Soussana. 2002. How can we predict the effects of elevated on the balance between perennial $\mathrm{C} 3$ grass species competing for light? The New Physiologist. 154:53-64.

Weaver, J.E. and R.W. Darland. 1949. Soil-root relationships of certain native grasses in various soil types. Ecol. Monographs 19:303-338.

Welker, J.M., J.T. Fahenstock, K.L. Povirk, C.J. Bilbrough, and R.E. Piper. 2004. Alpine grassland $\mathrm{CO}_{2}$ exchange and nitrogen cycling: grazing history effects, Medicine Bow Range, Wyoming, USA. Arctic Antarctic and Alpine Research. 36:11-20. 